\title{
The Color of Gender
}





\section{The Color of Gender}

Reimaging Democracy

Zillah R. Eisenstein

UNIVERSITY OF CALIFORNIA PRESS

Berkeley · Los Angeles · London 
University of California Press

Berkeley and Los Angeles, California

University of California Press, Ltd.

London, England

(c) 1994 by

The Regents of the University of California

\section{Library of Congress Cataloging-in-Publication Data}

Eisenstein, Zillah R.

The color of gender : reimaging democracy / Zillah R. Eisenstein. p. $\mathrm{cm}$.

Includes bibliographical references and index.

ISBN 0-520-08338-5 (alk. paper). — ISBN 0-520-08422-5 (pbk. : alk. paper)

1. Sexism. 2. Racism. 3. Patriarchy. 4. Democracy.

5. Feminism. I. Title.

HQ1237.E58 1994

$305.3-\mathrm{dc} 20$

Printed in the United States of America

9876554321

The paper used in this publication meets the minimum requirements of American $\mathrm{Na}$ tional Standard for Information Sciences-Permanence of Paper for Printed Library Materials, ANSI Z39.48-1984. @ 
For my daughter Sarah 
